\title{
First record of Diaphanosoma spinulosum Herbst 1975 (Cladocera: Sididae) for inland water bodies of Ecuador
}

\author{
C. López ${ }^{a b *}$ (D), L. M. Soto ${ }^{a}$ (D), W. Lafuente (i), M. García (D), F. D. Rocha-S $^{e}$ (D) and \\ P. de Los Ríos ${ }^{f}$ \\ aUniversidad Técnica de Manabí, Facultad de Ciencias Veterinarias, Escuela de Acuicultura y Pesqueria, Bahía de \\ Caráquez, Manabí, Ecuador

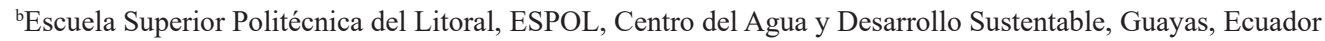 \\ 'Universidad Estatal del Sur de Manabí, Facultad de Ciencias Naturales y de la Agricultura, Carrera de Ingeniería \\ Ambiental, Manabí, Ecuador \\ dUniversidad de Barcelona, Facultad de Biología, Barcelona, España \\ 'Universidade Federal de Goiás - UFG, Laboratório de Taxonomia Animal, Unidade Acadêmica Especial de Ciências \\ Biológicas, Regional Jataí, Jataí, GO, Brasil \\ fUniversidad Católica de Temuco, Facultad de Recursos Naturales, Departamento de Ciencias Biológicas y Químicas, \\ Temuco, Chile \\ *e-mail: cllopez@utm.edu.ec; profc31@gmail.com
}

Received: October 1, 2019 - Accepted: March 18, 2020 - Distributed: August 31, 2021

(With 1 figure)

The genus Diaphanosoma Fisher, 1850 is widely distributed in the world, excepting Antarctica and New Zealand (Korovchinsky, 2018). According to Kotov et al. (2013), the genus Diaphanosoma comprise a total of 34 species, however, only one species (D. brachyurum Lieven 1848) is known in Ecuador (López et al., 2018). This occurrence is questionable because $D$. brachyurum represents a complex of species and populations out of natural distribution (Holarctic zone) might belong to sibling species (Elías-Guitiérrez et al., 1999; Korovchinsky, 2018). In Argentina, D. brachyurum should be assigned as D. birgei Kořínek, 1981 (Juan C. Paggi, personal communication). At least seven other species of the genus Diaphanosoma inhabit in South America (Paggi, 1978; Elmoor-Loureiro, 1998; Korovchinsky, 2018) and consequently some of these could be found in Ecuador. Here, the occurrence of Diaphanosoma spinulosum Herbst 1975 in Albarrada Martín Pescador, an artificial and temporal water body in Guayas Province of the Coastal region of Ecuador is recorded. This is the first record of this species for Ecuadorian inland waters (López et al., 2018).

The studied specimens were collected with a plankton net with pore mesh of $45 \mu \mathrm{m}$, preserved with $4 \%$ formalin, and these were analyzed and dissected with the aid of a stereomicroscope. Microphotographic images and measurements were made with NIS-Elements G software.

Examined material: Ecuador;Guayas Province, Guayaquil, Bosque Protector La Prosperina, Albarrada Martín Pescador (02 09'04.4 South' '-07957'56.2' West). Collected by Dr. Carlos López, María García and Wilson Lafuente, 9th June of 2017. Twenty-five parthenogenetic females.
The morphology of studied specimens agrees totally with description of D. spinulosum of Herbst (1975): (i) elongated body $(0.80-1.1 \mathrm{~mm})$, (ii) head rectangular strongly developed dorsally and with a large eye (Figure 1a), (iii) swimming antennae robust but not reaching the posterior margin of valves (Figure 1b), (iv) antennal formula setae 4-8/0-1-4, (v) ventral margin with a wide flap-inflexion, (vi) posteroventral margin of valves with 6-9 large curved spines, between each pair of massive spine there are 1-4 short spines decreasing of length towards posterodorsal angle of valves (Figure 1c), (vii) 2-4 groups of small marginal anal teeth on each side of postabdomen, (viii) distal spine on the terminal claw similar in length or slightly longer than proximal most ones, (ix) pecten of terminal claw with rather large denticles along ventral side which diminish distally (Figure 1d).

D. spinulosum was described by Herbst (1975) from samples of Lagartijo Reservoir, Venezuela. This is considered an endemic species from the Neotropics (Korovchinsky, 2018) and broadly distributed in the north region (De Roa and López, 2008; Fuentes-Reines, 2014; Kotov and Fuentes- Reines, 2015) and south of South America (Paggi, 1978; Valdivia-Villar, 1988). Thus, the presence of this species in Ecuador was expected. The present record is interesting because it expands the known geographical distribution of this species. Recent results of molecular analysis and morphological variations have indicated the presence of cryptic species in the genus Diaphanosoma (Lakatos et al., 2015; Liu et al., 2018). Thus, studies comparing morphological and genetic features of these coastal populations with populations from both sides of the Andes mountains of South America are required. 

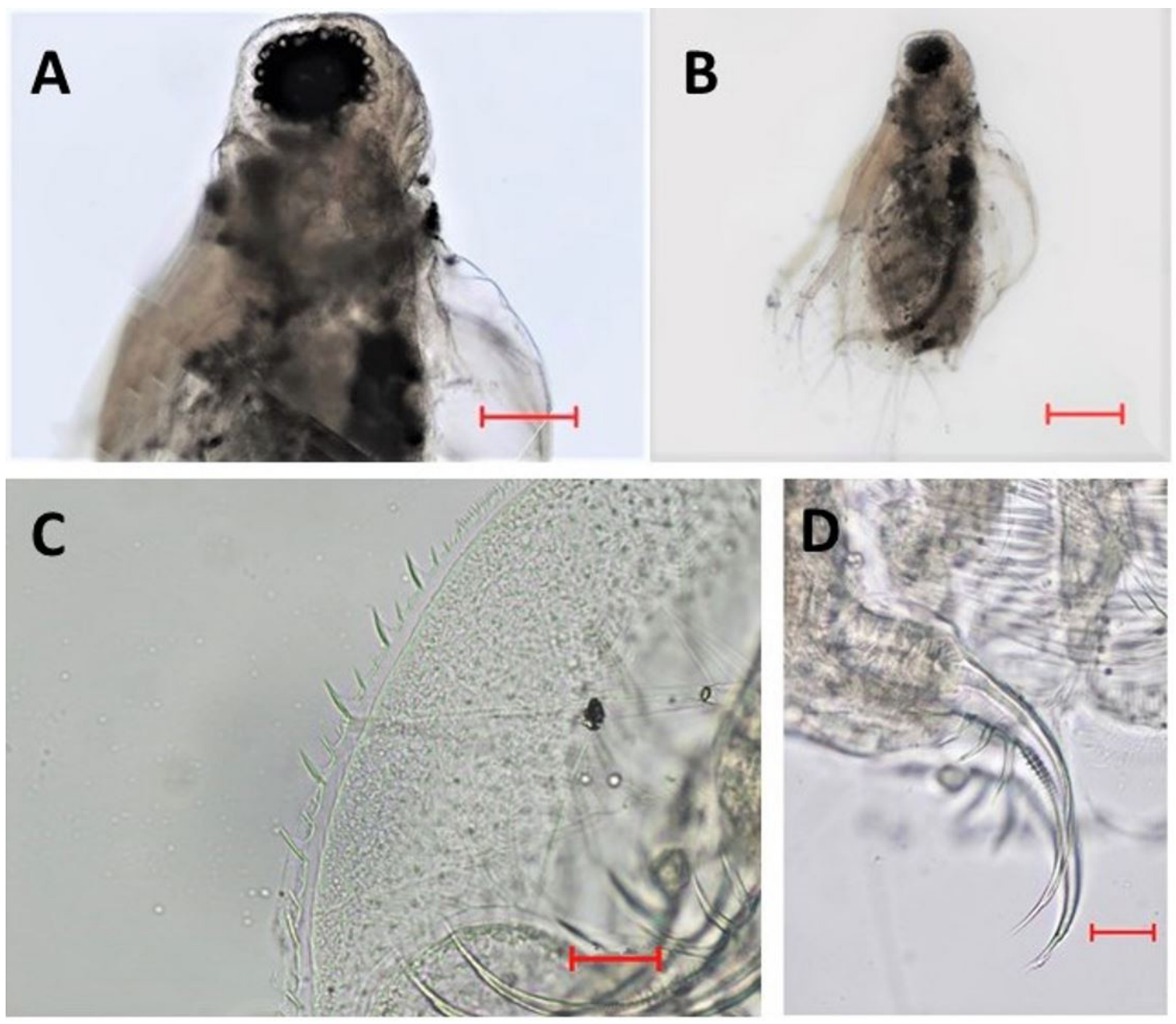

Figure 1. D. spinulosum specimens from Ecuador. (A) Head and eye (scale=200 $\mu \mathrm{m})$; (B) Lateral view $(\mathrm{scale}=100 \mu \mathrm{m})$; (C) Postero-ventral margin of valves $(\mathrm{c}=20 \mu \mathrm{m})$; (D) Post abdominal claw, lateral view $(\mathrm{scale}=20 \mu \mathrm{m})$.

\section{Acknowledgements}

Special thanks to M. Steinitz-Kannan for English grammar and spelling revision and M. López for help with photos. Our acknowledgements to Ministerio del Ambiente de Ecuador for permissions (MAE-UAF-DPAG-2017-3238-E).

\section{References}

DE ROA, E.Z. and LÓPEZ, C., 2008. An updated checklist of inland Cladocera (Crustácea: Superorders Ctenopoda and Anomopoda) from Venezuela. Zootaxa, vol. 1919, no. 1, pp. 45-57. http://dx.doi.org/10.11646/zootaxa.1919.1.3.

ELÍAS-GUITIÉRREZ, M., CIROS-PÉREZ, J., SUÁREZMORALES, E. and SILVA-BRIANO, M., 1999. The freshwater Cladocera (orders Ctenopoda and Anomopoda) of Mexico, with comments on selected taxa. Crustaceana, vol. 72, no. 2, pp. 1-16.

ELMOOR-LOUREIRO, L.M.A., 1998. Branhiopoda. Freshwater Cladocera. In: P.S. Young, ed. Catalogue of Crustacea of Brazil. Rio de Janeiro: Museu Nacional, pp.15-41.
FUENTES-REINES, J., 2014. Presence of Diaphanosoma spinulosum Herbst, 1975 (Crustacea: Cladocera: Ctenopoda, Sididae) in a coastal system of northern Colombia, with comments on D. birgei Kořínek, 1981. Boletin del Centro de Investigaciones Marinas, vol. 43, no. 2, pp. 407-413.

HERBST, H., 1975. Diaphanosoma spinulosum n. sp. (Crustacea, Cladocera) aus Venezuela. Gewässer und Abwässer, vol. 46, no. 57, pp. 7-11.

KOROVCHINSKY, N.M., 2018. Cladocera: ctenopoda: Families Sididae, Holopediidae \& Pseudopenilidae (Branchiopoda: Cladocera). In: DUMONT, H.J., eds. Identification guides to the plankton and benthos of inland waters. Weikersheim: Backhuys Publishers, Leiden \& Margraf Publishers, pp. 1-207.

KOTOV, A. and FUENTES-REINÉS, J., 2015. An annotated checklist of the cladocera (Crustacea: Cladocera) of Colombia. Zootaxa, vol. 4044, no. 4, pp. 493-510. http://dx.doi.org/10.11646/ zootaxa.4044.4.2.

KOTOV, A., FORRÓ, L., KOROVCHINSKY, N. and PETRUSEK, A., 2013 [viewed 6 May 2018]. World checklist of freshwater Cladocera species [online]. Available from: http://fada.biodiversity. be/group/show/17 
LAKATOS, C., URABE, J. and MAKINO, W., 2015. Cryptic diversity of Japanese Diaphanosoma (Crustacea: Cladocera) revealed by morphological and molecular assessments. Inland Waters, vol. 5, no. 3, pp. 253-262. http://dx.doi.org/10.5268/ IW-5.3.847.

LIU, P., XU, L., XU, S., MARTÍNEZ, A., CHEN, H., CHENG, D., DUMONT, H., HAN, B. and FONTANETO, D., 2018. Species and hybrids in the genus Diaphanosoma Fischer, 1850 (Crustacea: Branchiopoda: Cladocera). Molecular Phylogenetics and Evolution, vol. 118, pp. 369-378. http://dx.doi.org/10.1016/j. ympev.2017.10.016. PMid:29107154.
LÓPEZ, C., MOSQUERA, P.V., HAMPEL, H., NERETINA, A.N., ALONSO, M., VAN, D.K. and KOTOV, A.A., 2018. An annotated checklist of the freshwater cladocerans (Crustacea: Branchiopoda: Cladocera) of Ecuador and the Galápagos Islands. Invertebrates Zoology, vol. 15, no. 3, pp. 277-291. http://dx.doi. org/10.15298/invertzool.15.3.06.

PAGGI, J., 1978. Revisión de las especies argentinas del género Diaphanosoma Fischer (Crustacea, Cladocera). Acta Zoológica Lilloana, vol. 33, no. 1, pp. 43-65.

VALDIVIA-VILLAR, R., 1988. Lista de Cladóceros dulceacuícolas del Perú. Amazoniana, vol. 10, no. 3, pp. 283-297. 